\title{
誘導電動機の磁束検出
}

\begin{tabular}{|c|c|c|c|c|c|}
\hline 正 & 古 & 賀 & 国 & 夫 & （広島商船高専） \\
\hline 正 & 上 & 田 & 隆 & 三 & (東亜大学) \\
\hline 正 & 園 & 田 & 敏 & 勝 & (九州工大) \\
\hline 非 会 & 高 & 城 & 洋 & 明 & (九州工大) \\
\hline
\end{tabular}

\section{Detection of Magnetic Flux in Induction Motors}

Kunio Koga, Member (Hiroshima National College of Maritime Technology), Ryuzo Ueda, Member (University of East Asia). Toshikatsu Sonoda, Member (Kyushu Institute of Technology), Hiroaki Takajo, Non-member (Kyushu Institute of Technology)

Performances of vector controlled induction motor are improved by knowing the spacial position of the rotating magnetic flux in the induction motor at every instant. Usually, hole generators are buried in the teeth of the stator for detecting the air gap flux. However, this method is strongly affected with the slot ripple and does not work well due to the high temperature operating condition.

This paper proposes a novel and effective method for detecting the magnetic flux. Zero magnetic field sensor(MFS) is applied, which is buried in the yoke of the stator, since it has a wide operating temperature range $\left(-76 \sim 300^{\circ} \mathrm{C}\right)$ with the high accuracy of $0.1 \%$. Two components, radial component and tangential one, are investigated for which is more fit for the purpose. Both of them include no slot ripple but their wave distortion is inevitable owing to the nonlinearity of the core. Inadition, the value of the detected flux also varies as a function of the mounted position of MFS. Their degree is much smaller in the tangential component than that in the radial one. This signifies that the tangential component is profitable for our purpose. The effect of the wave distortion can be almost completely suppressed by properly arranging three MFSs based on the three phase theory without using any filters. DC flux at zero frequency can also be detected. Effectiveness of the proposed method is verified through these experimental investigation.

キーワード : 誘導電動機, 磁束検出, ベクトル制御, 磁束センサ, 回転磁界

\section{1.まえがき}

ベクトル制御の発展によって直流電動機が使用されていた 可変速分野にも誘導電動機が便用されるようになった。初期 のベクトル制御の開発段階では，誘導電動機の磁束（以下， 磁束と略記）を検出して制御する磁束制御形べクトル制御が 研究された(1)。この磁束検出は, ホール発電器を固定子の雨 に埋め込む必要がある。しかし，この検出方式は，ホール発 電器の温度ドリフトが大きく，かつ誘導電動機内部のような 高温環境では使用できないことと，検出磁束にスロットリッ プルが発生する問題がある(2)。そのため，磁束検出を必要之 しないスベリ周波数形ベクトル制御が，実用化された。スベ リ周波数形ベクトル制御は，パラメータの変動を受けやすい 問題がある。この問題を解決しベクトル制御の高性能化を図
るため, 誘導電動機の端子電圧および一次巻線電流の検出值 より得られた磁束を制御に使用する方式がある(3)。しかし， この方式は，一次電流が直流および低周波において検出誤差 が大きくなる問題がある。また，速度センサレスベクトル制 御は，一次電流が直流およびその近傍では不安定になる問題 がある(4)。これらの問題は，傢束検出によって解決するので 磁束検出が強く期待されている。

本論文では, 磁束㭘出における前述の問題を基本的に解決 する新しい眑束検出方式を示す。すなわち，磁束センサとし ては，零磁界形磁束センサを使用する(5)。この磁束センサは， アモルファスコアを使用するので温度ドリフトが小さく，か つ $300^{\circ} \mathrm{C}$ ま゙使用でき誘導電動機内での使用が可能である。 また，磁束センサは，誘導電動機のヨーク部に設置するので 
スロットリップルが発生しない。

本諭文では，まず，ヨーク部内に存在する半径方向磁束上 接線方向磁束とでは，どちらが検出に適するかを理論および 実験で検討し接線方向磁束が適することを明らかにする。次 に検出磁束に含まれる高調波成分を除去する方法を示し，実 験によってその効果を検証する。また，直流磁束に対する基 本波と高調波の概念を明らかにする。

\section{2. 磁束センサの位置と磁束検出方向}

この章では，適した磁束センサの位置およびヨーク部磁束 の検出方向を理論および実験で検討する。

〈2・1〉磁束センサの位置最初に磁束センサの位置を 明らかにする。従来の磁束検出では，固定子スロットの雨に 磁束センサが設置されていた。しかし，この方式では，固定 子スロットの菌と回転子スロットの歯とが一致したとき検出 磁束が大きくなり，一致しないときに小さくなる。いわゆる スロットリップルが発生する。また, 固定子スロットの雨は, 誘導電動機の内部に位置し高温になりホール発電器の温度ド リフトが大きいことと，その許容温度を超え使用できない場 合がある。このため，この方式は実用化されなかった

図 1 は, 供試汎用誘導電動機 $2.2[\mathrm{~kW}], 4$ 極, $220[\mathrm{v}]$, $60[\mathrm{~Hz}], 1750[\mathrm{rpm}]$ の固定子鉄心の断面図と平面図を示してい る。ここでは，磁束センサを固定子スロットの歯に設置する ことをやめ図 1 に示すように固定子のヨーク部に設置する。 磁束センサ用穴は，直径 $5[\mathrm{~mm}$ ?であり，その面積の固定子 1 極当たりの表面積に対する割合は, $1.83[\%]$ とさく誘導電動 㙨の特性に影響を与えない。磁束センサ用穴の梁さは $15[\mathrm{~mm}]$ であり，スロットの底より $3[\mathrm{~mm}]$ 離している。磁束センサは， 深さ $4.7[\mathrm{~mm}]$ の位置に設置している。

磁束センサの最少個数は，原理的に電気角で $90^{\circ}$ 離れた 2 個でよい。しかし，図 1 では磁束センサは，3 個使用してい るが，その理由は第3章で述べる。

〈2.2〉接線方向磁束と半径方向磁束の比較 $\exists ー ク$ 部 には，図1に示すように接線方向磁束 $\phi_{\mathrm{x}}$ 之半径方向磁束 $\phi_{\mathrm{y}}$ が存在する。磁束検出としては，どちらの方向が適するか理 論的に検討する。概略の検討を行うためリ二ア誘尊電動機上 して考察する。図 2 は, リニア誘導電動機の $\mathrm{x}, \mathrm{y}$ 平面での断 面図である。 $\mathrm{z}$ 軸は， $\mathrm{x} ＼textrm{y}$ 軸に直角で誌面の裹面より表面に 向かっている。 $\mathrm{z}$ 軸方向の磁束分布は，一様と仮定する。誘 導電動械内の磁束分布の検討は，無負荷時の励磁電流のみ流 れている状態でできるので回転子の電流は考慮していない。 固定子鉄心の厚さは $\mathrm{h}$, 法腺の長さは $\mathrm{g}$ である。さらに, スロ ットは無視し，鉄心のヒステリシス等の非線形性および鉄心 内の渦電流は無視する ${ }^{(6)}$ 。また鉄心の比透磁率は十分に大き いと仮定する。固定子鉄心の $\mathrm{z}, \mathrm{x}$ 平面には， $\mathrm{z}$ 軸に平行な単
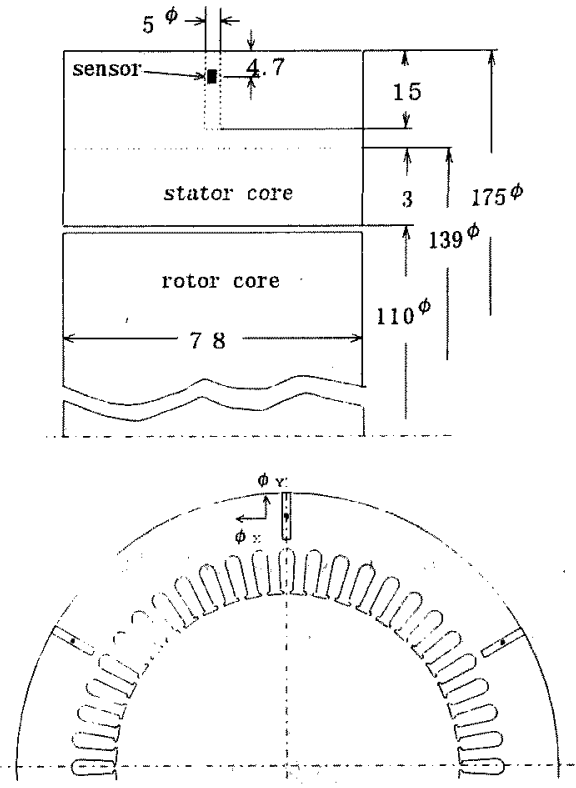

図 1 磁束センサの配置

Fig. 1 Arrangement of magnetic flux sensors.

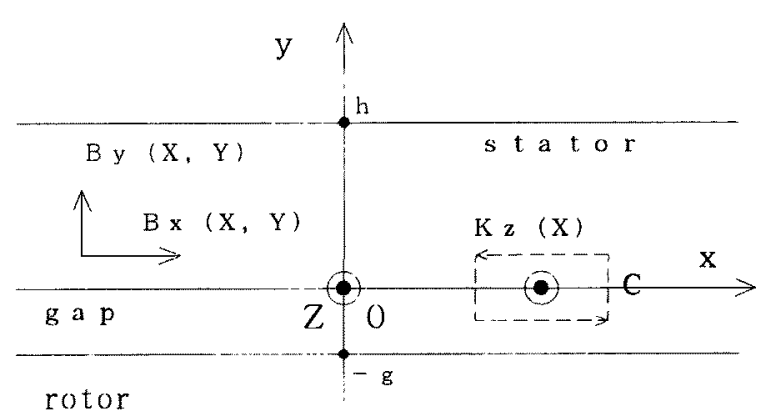

図 2 リニア誘導電動機

Fig. 2. Linear induction motor.

位長あたりのシート電流 $K_{\mathrm{Z}}(x)$ が流れているものと仮定する と $K_{Z}(x)$ は次式で示される。

$$
\begin{aligned}
& K_{z}(x)=i \cos \beta x \ldots \ldots(1) \\
& \beta=\frac{2 \pi}{\lambda} \ldots \ldots \ldots(2)
\end{aligned}
$$

ここに， $\lambda$ は，電流の波長を示す。iは，励磁電流を示し 時間関数である。固定子鉄心および回転子鉄心には電流が流 れないので，静磁界として解析でき次式が成立する。

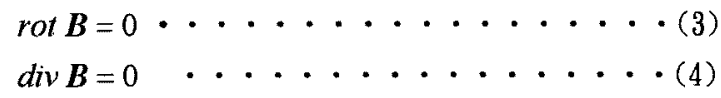

ここに，Bは磁束密度でありBの $x$ および $y$ 方向成分ををれ ぞれ $B_{X} ， B_{Y}$ とすると次式で示される。 


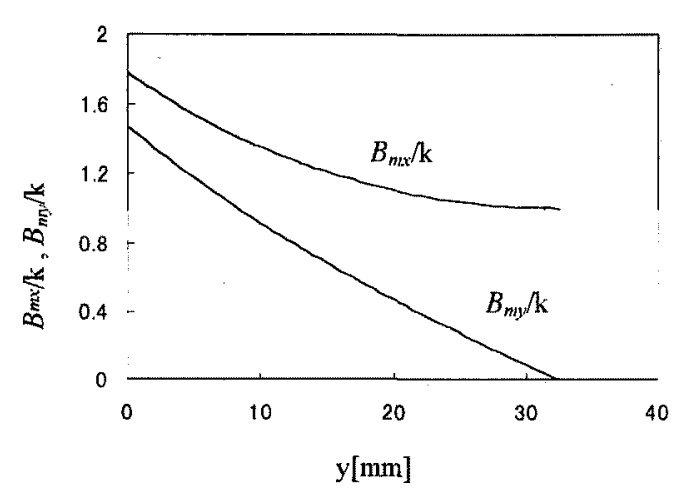

図 3 磁束振幅特性

Fig. 3. Characteristics of magnetic flux amplitude.

$\boldsymbol{B}=\left\{B_{X}(x, y), B_{Y}(x, y)\right\} \cdots \cdots(5)$

$B の \mathrm{z}$ 方向成分 $B_{Z}$ は, 零と仮定する。従って, $B_{Z}$ は，(5) 式に含まれない。 $B_{Z}$ が零の条件と(3)，(4)式より次の関係 式が得られる。

$$
\begin{aligned}
& \left(\frac{\partial^{2}}{\partial x^{2}}+\frac{\partial^{2}}{\partial y^{2}}\right) B_{x}=0 \cdots \cdots \cdot(6) \\
& \left(\frac{\partial^{2}}{\partial x^{2}}+\frac{\partial^{2}}{\partial y^{2}}\right) B_{y}=0 \cdots \cdots \cdot(7)
\end{aligned}
$$

次に, 図 2のループCにアンペアの周回積分の法則を適用 する上次式が得られる。ただし，ルーナ゚Cのy方向の距㕍忙 十分に短いものとする。

$$
B_{x}(x, 0)=\mu_{0} i \cos \beta x \cdots \cdots(8)
$$

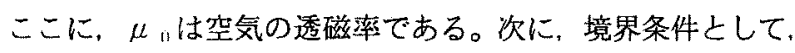
(I) 固定子鉄心外の磁束密度は零, (II) y が零において固定 子鉄心内の磁束密度の $y$ 方向成分亡空隙内の磁束密度の $y$ 方 向成分が等しい，(II) $y$ が-gに执いて磁束密度の $x$ 方向成 分が零および(IV)（8)式による条件を定める。これらにより

(6)，(7)式の解として次式が得られる。

$$
0 \leqq y \leqq \mathbf{h}
$$$$
\begin{aligned}
& B_{x}(x, y)=-B_{m x} \cos \beta x \quad \ldots \ldots(9) \\
& B_{y}(x, y)=B_{m y} \sin \beta x \quad \ldots \cdots(10)
\end{aligned}
$$
$\Xi こ に$.

$$
\begin{aligned}
& B_{m x}=k \cosh \beta(h-y) \\
& B_{m,}=k \sinh \beta(h-y) \cdots \cdots \\
& k=\frac{\mu_{0} i}{\tanh (\beta g) \sinh (\beta h)} \cdots \cdots(11) \\
& \cdots \cdots \cdot(12)
\end{aligned}
$$

$B_{x}(x, y)$ お。よび $B_{y}(x, y)$ の振幅 $B_{m x}, B_{m y}$ は，(11)，(12)式で 表される。この特性を供試誘導電動機の諸元を用いて計算し た結果を図 3 に示している。ただし，gは０.6[mm]である。

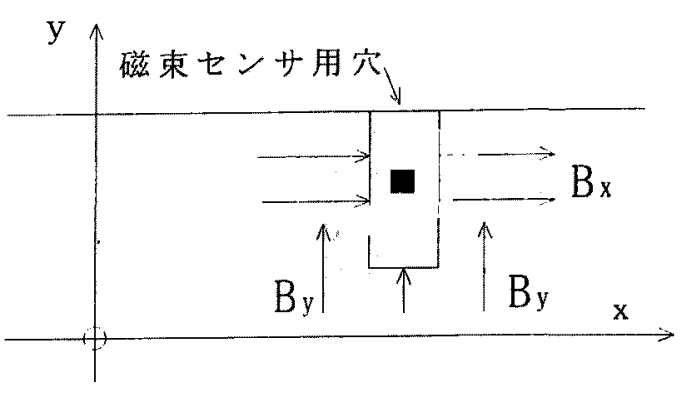

図 4 磁気シールド効果

Fig. 4. Effect of magnetic shield.

図 3 より明らかなように， $B_{n y}$ は，yの変化に対して大き く変化するが $B_{m x}$ の変化は小さい。これは，接線方向磁束検 出が、半径方向磁束検出より磁束センサの位置変化に対して ロバストであり有利であることを意味している。また，磁束 レベルの面でも接線方向が半径方向より高く，有利である。

〈2・3〉磁気シールド効果図 1より明らかなように磁 束センサは，強磁性体である鉄心の中に設けられた磁束セン サ用穴の中に設置されるので一種の磁気シールドされた状態 にあるとみなされる。この場合，図 4 に示すように接線方向 磁束密度 $B_{x}$ に対してはセンサ用穴は, 扁平棈造であり磁気シ 一ルド効果は小さい。しかし, 半径方向磁束密度 $B_{y}$ に対して は奥行きが深く磁気シールド効果は, 大きくなる。このため, 接線方向磁束の検出が、半径方向より検出レベルが高くなり 検出に適する。

次に検出歪みについて考察する。ヨーク部磁束めは, セン サ用穴を通る磁束 $\varnothing_{s}$ とそれ以外の鉄心を通る磁束 $\phi_{1}$ に分流 する。この場合の分流割合は，センサ用穴の磁気抵抗 $R_{s}$ とそ れ以外の鉄心の磁気抵抗 $\mathrm{R}_{\mathrm{i}}$ によって決まる。しかし， $\mathrm{R}_{\mathrm{s}}$ は 空気で構成されるので線形であるが $\mathrm{R}_{\mathrm{i}}$ は鉄心のヒステリシス 特性や飽和特性のために非線形となる。従って，申が正弦波 であっても磁束センサの検出磁束は，歪むことになる。この 場合，磁気シールド効果が大きいほど歪みの度合いは大きく なるので，磁気シールド効果の小さい接線方向の磁束検出が 適する。また，鉄心の磁気飽和が大きいほど検出磁束の歪み が大きくなるので，鉄心は飽和しない籁用で使用するのが良 W。

〈2・4〉予備実験結果 以上の検討によって磁束検出と しては，接線方向磁束の検出が適することが分かった。そこ で、確認を行うためホール発電器を使用して予備実験を行っ た。図 5 にその結果を示している。予備実験用の $2.2[\mathrm{~kW}]$ 誘 導電動機を $220[\mathrm{~V}] ， 60[\mathrm{~Hz}]$ の商用電源で無負荷運転した場合 である。図5(a)は，半径方向磁束の検出結果である。固定子 鉄心の表面より深さ $D[\mathrm{~mm}]$ の位置にホール発電器を配置し た。Dを $15[\mathrm{~mm}] よ り 12 ! \mathrm{mm}]$ に減少させると磁束の振幅が急速 
に滅少し，波形歪みも大きくなることが分かる。なお，同図 では励磁電流 $i$ も表示している。図 5(b)は，接線方向磁束の 検出結果である。Dを $3[\mathrm{~mm}]$ より $15[\mathrm{~mm}]$ まで変化させている が，磁束振幅の変動は小さく，波形歪みも小さいことが分か る。以上の実験結果は，理論的に接線方向磁束の検出が適す るという結果の妥当性を示している。

\section{3. 交流磁束の検出}

前章において磁束検出は，接線方向磁束の検出が適するが 波形歪みが発生する問題が明らかになった。この章では，ま ず，誘導電動機内のような厳しい環境での磁束検出が可能な 雾磁界形磁束センサの概要について述へ，その後，高調波磁 束の抑制方法と検出磁束の特性を述べる。

〈3・1〉零磁界形磁束センサ 本研究で使用する磁束セ ンサは，角形ヒステリシス特性を有するアモルファスコアの

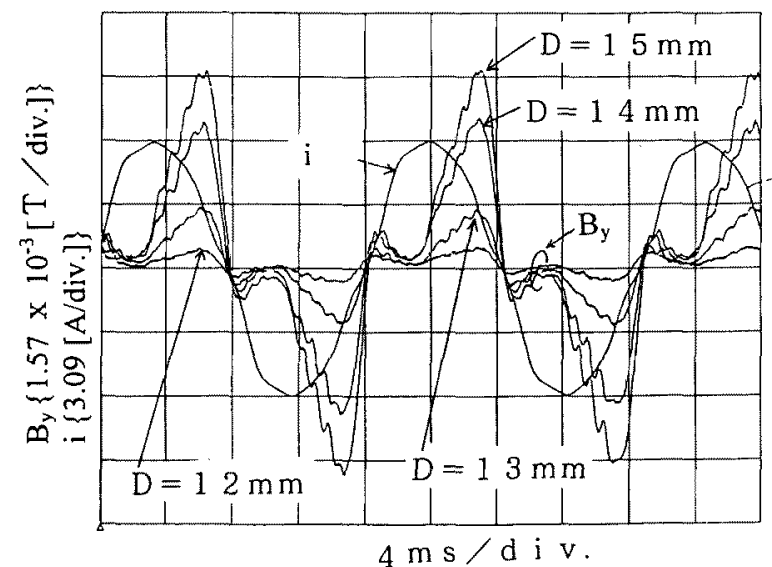

(a)半径方向磁束

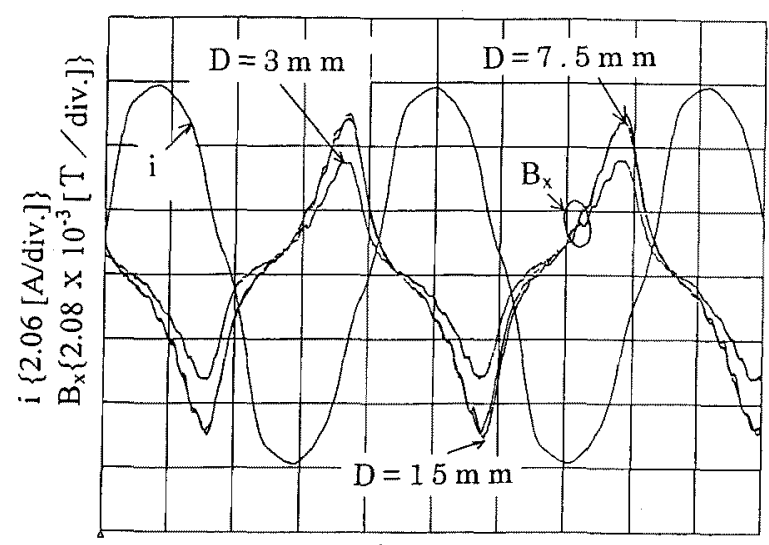

$4 \mathrm{~ms} / \mathrm{div}$.

(b)接線方向磁束

図 5 接線方向磁束上半径方向磁束の测定結果 Fig. 5. Measured magnetic flux of tangential and radial component. (a) radial component. (b) tangential component.
磁界を零にすることによって磁束を测定する方式で $300^{\circ} \mathrm{C} の$ 高温でも使用可能であり，かつ10 11" [T]の低レベルの磁界が 検出できる(5) 。従って, 磁束検出用穴のような磁気シールド された状態の磁束も㭘出できる。さらに，原理的に温度フリ 一であり0.1[\%]以下の高精度の検出ができる。周波数特性は，

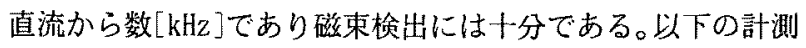
ではここの零磁界形磁束センサを使用した。

〈3・2〉第 3 調波の㧕制磁束検出にあたって磁束セン サを使用すると同時に比較のために誘導電動機にサーチコイ ルを巷き，その電圧を積分して磁束を求めた。また，誘導電 動機の制御は，停止状態より高速まで测定するので速度セン サ付きベクトル制御とした。

図 6 に16.9[Hz]，然負荷での磁束検出波形例を示している。 サーチコイルによる検出磁束は正弦波であるが，磁束センサ の検出值には柾みが見られる。しかし，スロットリップルは， 表れていない。磁束センサの検出值は，正の波形と負の波形 が等しいので奇数次の高調波成分を含むことが分かる。図 6 亡同様な波形を誘導電動機の周波数 $f$ を黍化させて测定し， 周波数分析を行った結果を図 7に示している。負荷を-100[\%] から 100[\%]まで変化させた場合も, 図 7 とほぼ同じ結果が得 られた。図 7 より第 3 調波成分が $13.5 \sim 25[\%]$ ，第 5 調波成 分が 2.5〜3.1[\%], 第 7 調波成分が 0.3〜0.5[\%]含まれている ことが分かる。特に，第 3 調波成分が大きく主要な高調波成 分であることが分かる。この第 3 調波成分を除去する方法之 してフイルタの使用が考えら机る。しかし、ベクトル制御で は，誘尊電動機の一次電流が直流になる場合も使用するので フイルタは使用できない。すなわち，直流では基本波と高調 波の区別がつかないからである。従って，ここではフイル夕 を使用せずに第 3 調波成分を除去することを考える。

第 3 調波等の 3 の倍数調波成分は，対称 3 相回路において は瞬時值の等しい同相成分になる。そこで，図はに示すよう

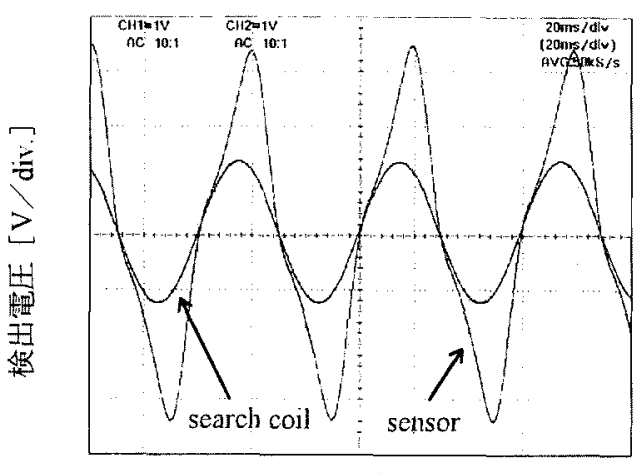

$\mathrm{t}\{20[\mathrm{~ms} / \mathrm{div}]\}$

図 6 検出磁束波形

Fig. 6. Waveforms of detected magnetic flux. 


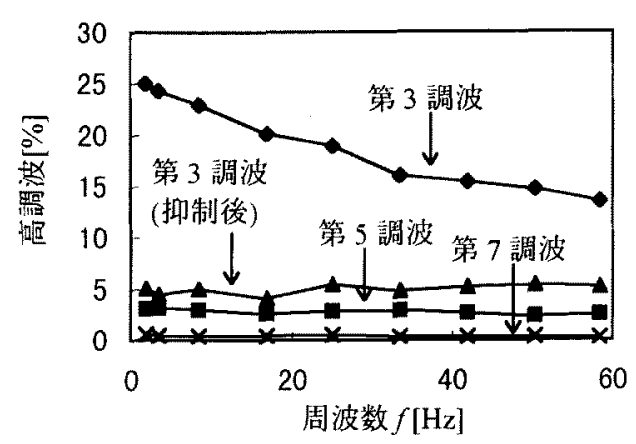

図 7 高調波

Fig. 7. Higher harmonics

に3 個の磁束センサを電気角で $120^{\circ}$ 離して配置する。3 個の 磁束センサの出力を $\phi_{a} ， \phi_{b}, \phi_{c}$ として次式により磁束の d, q 軸成分 $\phi d, \phi$ 在演算する。

$$
\begin{aligned}
& \phi_{d}=\frac{\left(\phi_{c}-\phi_{b}\right)}{\sqrt{3}} \ldots \ldots(14) \\
& \phi_{q}=\frac{2 \phi_{a}-\phi_{b}-\phi_{c}}{3} \cdots \cdots \cdots(15)
\end{aligned}
$$

（14）（15）式とも，検出磁束の 2 相分の差の演算が行われて いるので，3 の倍数調波成分は相殺するが基本波成分は相殺 しない。図 7 の第 3 調波(㧕制後)で表示している曲線がめ であり抑制效果を示している。低周波においては，粕1/5に 抑制されていることが分かる。抑制後の検出磁束の波形例を 図 8 に示している。抑制後の残留值として第 3 調波が約 $5[\%]$ 存在するのは, 固定子鉄心のヨーク部には組み立て用の穴等が あり厳密には対称構造でないためと思われる。

〈3・3〉振幅および位相特性周波数および負荷を変え て検出磁束 $\phi_{q q}$ の振幅と位相遅れ角をサーチコイルの電压を 積分して検出した值と比較した結果を.図 9 および図 10 に示

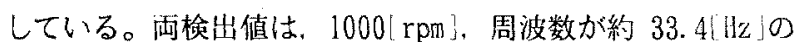
よきを 100[\%]にしている。図 9よりサーチコイルによる検出 值之の振幅差は，約 $10[\%]$ 以内であることが分かる。図 10 は, め $q$ のサーチコイルによる検出値に対する位相遅れ角を示し ている。同図上り位相遅れ角は，約 $12 \sim 20^{\circ}$ 以内である。

磁束の高精度検出が必要な場合は，検出值を補正する必要 があるが，最近のインバータはディジタルシグナルプロセッ サ等を装储しているので比较的簡単に補正できると思われる。

\section{4. 直流磁束の検出}

第 2 章では，回転磁界が回転している場合の磁束である交 流磁束の検出に関する問題について述べたこの章では，回 転磁界が静止した状態について考察する。この場合の榆出磁 束は，時間的には直流になるので直流磁束と呼ぶことにする。 《4・1〉直流磁束の高調波直流磁束の場合, 誘導電澌

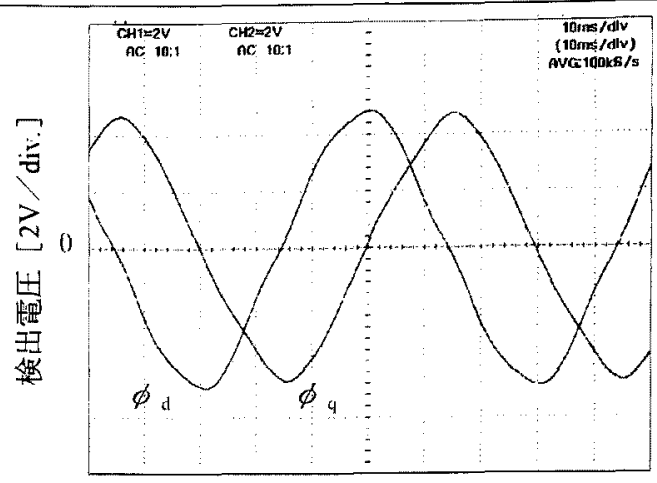

$\mathrm{t}\{10[\mathrm{~ms} / \mathrm{div}]$.

図 $8 \phi_{\mathrm{d}}, \phi_{\mathrm{l}}$ 波形

Fig. 8. Waveforms of $\phi_{\mathrm{d}}$ and $\phi_{4}$.
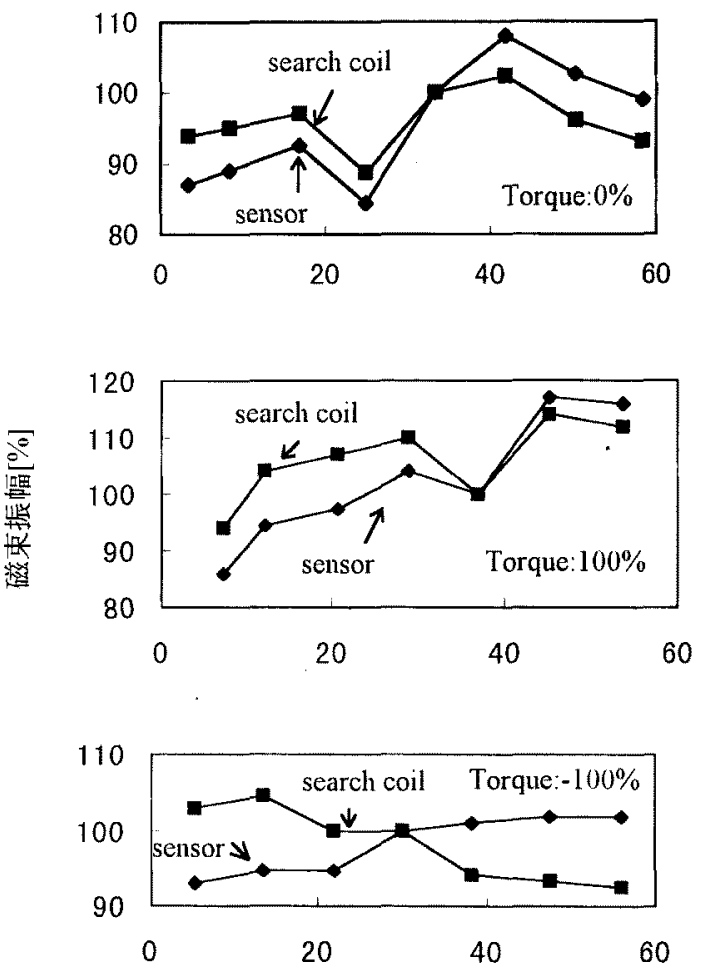

周波数 $f[\mathrm{~Hz}]$

図 9 検出磁束の振幅変動

Fig. 9. Amplitude variation of detected magnetic flux

機内の磁束分布が坒間的に正弦波でも磁束検出で歪みが発生 する場合と発生しない場合では磁束梚出值に差が生じる。す なわち，検出歪みは，検出直流電压の差として表れる。また， 直流磁束は, 直流電圧しして検出されるので周波数分析器を 使って図 7 のような高調波分析はできない。

しかし，直流磁束でも，高調波磁束と基本波磁束を定義で きれば高調波磁束の抑制方法などの検討に都合がよい。従っ て、以下にこれらの定義を行うことにする。 
ここでは，検出磁束は歪まないが誘導電動機内の空間磁束 が等価的に歪んでいると考える。そこで，最も簡単な基本波 と一つの高調波成分が存在する場合を考える。この方法は， 多くの高調波成分を含む場合にも容易に搪張できる。検出磁 束 $\phi は ，(16)$ 式で示される。

$$
\begin{array}{r}
\phi=\Phi_{1} \sin \left(\varpi t-\frac{2 \pi x}{\lambda}+\delta_{1}\right)+\Phi_{n} \sin \left\{n\left(\varpi t-\frac{2 \pi x}{\lambda}\right)+\delta_{n}\right\} \\
\ldots \ldots(16)
\end{array}
$$

（16)式で入は波長， $\delta_{1}, \delta_{\mathrm{n}}$ は位相角， $\omega$ は角周波数， $x$ は空間位置である。 $x$ が零のときの $\phi を \phi_{d}, x$ が $/ 4$ のと きのфを $\phi_{q}$ とすると $\phi_{d} ， \phi_{q}$ は次式の上うになる。

$$
\begin{aligned}
& \phi_{d}=\Phi_{1} \sin \left(\varpi t+\delta_{1}\right)+\Phi_{n} \sin \left(n \varpi t+\delta_{n}\right) \cdots(17) \\
& \phi_{q}=-\Phi_{1} \cos \left(\varpi t+\delta_{1}\right) \pm \Phi_{n} \cos \left(n \varpi t+\delta_{n}\right) \cdots(18)
\end{aligned}
$$

(18)式の復号の+は，nが3,7,11，一の場合であり，一は $5,9,13 \cdots$ 一場合である。ただし，偶数調波は含まれてい ないものとする。(17)，(18)式は，交流の場合，従来の基本波

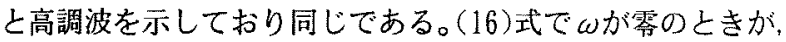
直流の場合である。この場合（16)式の第 1 項扰よび第 2 項 が $\boldsymbol{x}$ に関して基本波と $\mathrm{n}$ 倍調波となるので，これらを直流に 対する基本波书よびn倍調波と定義する。

〈4・2〉実験結果 直流では比較のためのサーチコイル よる磁束検出は使用できないので，固定子に直流電流を流し て磁束検出値と比較した。誘導電動機が停止状態のとき一次 巻線に直流電流を流すと，この電流はすへて励磁電流になる ので検出磁束と比較できる。いま, a 相の励磁電流を(19)式

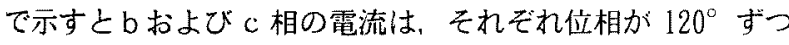
暑れた電流となる。

$$
i_{a}=I_{n} \sin (\omega t) \cdots \cdots \cdots(19)
$$

周知のように対称 3 相交流では，電流が 2 線間のみ流れる 瞬間が存在する。その瞬間は， $\omega \mathrm{t}$ が、 $0^{\circ}, 60^{\circ}, 120^{\circ} \cdots$

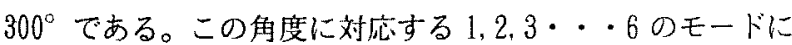
ついて誘導電動機の 2 線間に励磁電流に等しい直流電流 $I_{1}$ を 流して磁束を検出する。本実験では， $\mathrm{I}_{10}$ は $\mathrm{I}_{\mathrm{m}}$ の $86.6[\%] に$ 相当し 2.92[A]である。誘導電動機は，デル夕結線であるの で線電流之相電流とでは $30^{\circ}$ の位相差が発生する。磁束セン サは，相電流によって発生した磁束を検出するように配置し ているので各モードでの磁束べクトルは，図11 の様になる。 ここで各ベクトルの大きさは hI ${ }_{n}$ である。hは比例定数であ る。

図11で1〜6は各モードを示している。と6のモードは， $\mathrm{d}$ 軸と $30^{\circ}$ の角度を有している。各モードは，各々 $60^{\circ}$ の間 隔有している。図 11 より各モードのd 軸成分磁束め ‘的

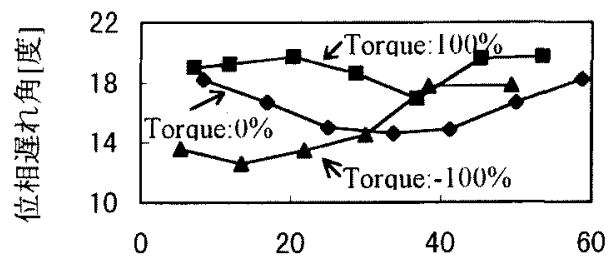

周波数 $f[\mathrm{~Hz}]$

図 10 検出磁束の位相達れ

Fig. 10. Phase lag of detected magnetic flux

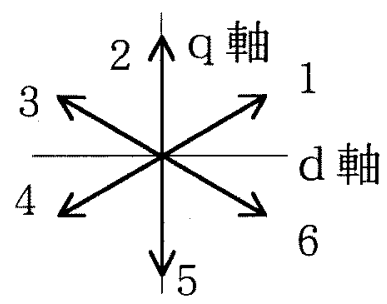

図11 ベクトル図

Fig.11. Vector diagram.

表 1 静止磁束

Table 1. Stationary magnetic flux

\begin{tabular}{|c|c|c|c|}
\hline mode & $\phi_{\mathrm{d}}$ & $\phi_{\mathrm{u}}$ & $\left(\phi_{\mathrm{d}}{ }^{2}+\phi_{\mathrm{u}}{ }^{2}\right)^{1 / 2}$ \\
\hline 1 & $0.986 / 0.866$ & $0.434 / 0.5$ & $1.078 / 1$ \\
\hline 2 & $0.028 / 0$ & $1 / 1$ & $1 / 1$ \\
\hline 3 & $-0.848 /-0.866$ & $0.416 / 0.5$ & $0.945 / 1$ \\
\hline 4 & $-0.822 /-0.866$ & $-0.481 /-0.5$ & $0.953 / 1$ \\
\hline 5 & $0.068 / 0$ & $-0.977 /-1$ & $0.979 / 1$ \\
\hline 6 & $0.963 / 0.866$ & $-0.435 /-0.5$ & $1.056 / 1$ \\
\hline
\end{tabular}

軸成分磁束 では，この理論值に対応する磁束の測定值を分子で示してい る。ただし，モード2のめ、基準としていで表している。 モード 2 と $50 \varnothing$ はは，磁束が空間的に正弦波なら零である。 実際には， 3 相間のバラツキ等によって 3 の倍数次調波も若 干残るので零にはならない。また磁束の大きさの埕差は, 最 大で7.8[䍖]である。表1の值は，全体的に見て理論值之実験 值の差がさく第 3 調波の抑制效果を示している。

\section{5.むすび}

本論文では，固定子ヨーク部に設置した磁束センサによっ て誘導電動機の磁束を检出する方式を明らかにした。接線方 向磁束娭出上半径方向磁束㭘出の比較では，接線方向磁束検 
出が適することが分かった。接線方向磁束検出においては， スロットリップルは表れないが鉄心の非線形性のため検出歪 みを発生する。フイルタを使用しないで検出歪みを抑制する 方法を提案し，その効果を実験で確認した。また，回転磁界 が静止した場合の直流磁束に対する基本波と高調波の定義を 行った。

最後に，本研究の一部は平成 8 年度文部省科学研究費基盤 研究(C)の援助によるものであることを付記し，誌面を借りて 関係者に謝意を表す。

(平成 9 年 4 月 23 日受付, 平成 9 年 8 月 14 日再受付)

古賀国夫（正員）昭和 17 年 3 月 28 日生。 42 年 3 月九州

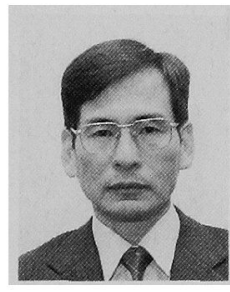

工業大学工学部第二部電気工学科卒業。(株) 安川電機を経て, 平成 4 年 4 月広島商船高等専 門学校電子制御工学科教授，現在に至る。工学 博士。主として, 交流電動機駆動システムおよ び非線形システムの応用に関する研究に従事。 1990 年 IEEE/IAS 論文賞受賞。

上田隆三（正員）昭和 15 年 12 月 15 日生。 45 年 3 月九州

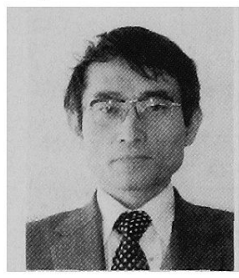

工業大学大学院工学研究科電子工学専攻修士 課程終了。4 5 年 4 月九州工業大学電子工学科助 手, 49 年 4 月同第二部電気工学科講師, 50 年 7 月同助教授, 学部改組により電気工学科教授。 平成 9 年 6 月東亜大学大学院教授, 現在に至る。 工学博士。電力系統の安定性, センサなどに関 する研究に従事。1990 年 IEEE/IAS 論文賞受賞。 IEEE 会員。
文献

(1) Felix Blaschke:"Das Prinzip der Feldorientierung, die Gru-dlage für die Transvekctor-Regelung von Drehfeldmaschine-n" Siemens-Z. 45 S. 757 bis 760 (1993)

（2）中野, 他:「ベクトル制御の開発裏話」，電学論 D, 114, 1(平 6-1)

（3）多田隈，他:「FF/FB 制御を用いた誘導機のベクトル制御方式」, 電気学会全大 No. 1492(昭 63)

（4）古賀，他:「速度センサレスベクトル制御における低速域での不安 定性について」，電気学会全大 No. 653(平 5)

（5）園田, 上田:「零磁界形磁界センサ」, 電学論 C, 110, 699(平 2-11)

（6）森田，他:「漏机磁束検出法による誘導電動機のかご形回転子の異 常診断」, 計測自動制御学会論文誌 Vol. 29, No. 11, 1269(平 5)

園 田敏 勝（正員）昭和 19 年 3 月 7 日生。 41 年 9 月東海大

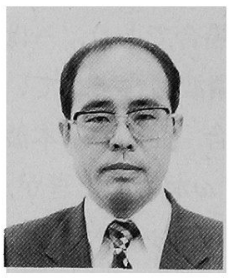
学短期大学部 (二部) 電気工学科 2 年中退。 41 年 8 月九州大学工学部技官, 46 年 4 月九州工業 大学工学部技官, 51 年 5 月九州工業大学助手, 現在に至る。工学博士。可変速ドライブシステ ムおよび検出器に関する研究に従事。1990 年 IEEE/IAS 論文賞受賞。日本非破壊検查協会, 日 本応用磁気学会, IEEE 会員。

高 城 洋 明（非会員）昭和 19 年 4 月 16 日生。 49 年 3 月北海

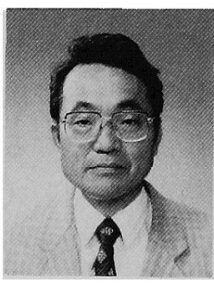
道大学大学院工学研究科電子工学専攻博士課 程終了。工学博士。 50 年 1 月九州工業大学電子 工学科講師。現在，同助教授。電磁気および光 工学に関する研究に従事。電子情報通信学会, OSA 会員。 